\title{
Representasi pesan lingkungan dalam Sexy Killers
}

\author{
Muhammad Ariq Anhasdio Faiz ${ }^{1}$, Aceng Abdullah ${ }^{2}$, Rangga Saptya Mohamad Permana ${ }^{3}$ \\ 1,2,3 Universitas Padjadjaran, Bandung, Indonesia
}

\begin{abstract}
ABSTRAK
Sexy Killers merupakan sebuah film dokumenter mengenai dampak dari penggunaan PLTU dan permasalahan lingkungannya. Penelitian pada artikel ini bertujuan untuk mengetahui representasi pesan lingkungannya melalui analisis dampak, sisi pesan dampak, tendensi pesan, fungsi komunikasi lingkungan yang digunakan, dan penggunaan critical rhetoric. Penelitian ini menggunakan pendekatan kuantitatif melalui metode penelitian deskriptif dengan menganalisis isi. Hasil penelitian menunjukkan dampak biologis pada unit sosial individu paling banyak dimunculkan sebanyak 40,54 persen adegan, sedangkan pada unit sosial masyarakat yang paling banyak adalah dampak lingkungan hidup yakni sebanyak 70,27 persen adegan. Sisi pesan paling banyak dimunculkan berupa satu sisi pesan sebanyak 91,89 persen adegan. Tendensi pesan paling banyak memiliki tendensi pesan negatif dengan porsi 91,89 persen adegan. Sexy Killers memiliki kedua fungsi komunikasi lingkungan yakni pragmatic dan constitutive yang ada dalam 95 persen adegan. Selain itu, Sexy Killers merupakan film dokumenter yang memuat critical rhetoric karena terdapat tindakan mengkritisi kebijakan penggunaan batu bara sebagai sumber energi pembangkit listrik dan penggunaan PLTU dalam 94,59 persen adegan. Hadirnya Sexy Killers membuktikan usaha pelestarian lingkungan. Hal ini tidak terbatas pada film yang mengandung critical rhetoric saja, namun dengan adanya film tersebut diharapkan mampu menjadi pemicu untuk menyadarkan khalayak dalam melestarikan alam di sekitar kita dengan turut berkontribusi untuk mengurangi penggunaan sumber energi batu bara dan kemudian mulai mengganti dengan energi surya yang lebih ramah lingkungan.
\end{abstract}

Kata-kata kunci: Analisis isi; komunikasi lingkungan; representasi; film dokumenter; Sexy Killers

\section{Environmental message representation in the Sexy Killers}

\begin{abstract}
"Sexy Killers" is a documentary about the impact of using steam power plants and its environmental problems. The research aims to determine the representation of environmental messages in the film through impact analysis, the message side of the impact, message tendencies, environmental communication functions, and critical rhetoric in the Sexy Killers documentary. This study used a quantitative approach through the descriptive research method by analyzing the content. The results showed that the biological impact in the individual social units was shown for 40.54 per cent of scenes, while the environmental impact in the public social unit was shown for 70.27 per cent of scenes. The message side in representing the impact mainly was one side, 91.89 per cent of the scene. The tendency of the impact message had a negative message tendency in 91.89 per cent of the scene. Sexy Killers had both pragmatic and constitutive environmental communication functions, present in 95 per cent of the scene. In addition, Sexy Killers is a documentary that contains critical rhetoric because several actions criticize using coal as the energy source of power plants in 94.59 per cent of the scenes. The presence of Sexy Killers proves environmental conservation efforts. This is not limited to films that contain critical rhetoric only. However, the existence of these films becomes a trigger of audiences awareness in conserving nature around us by contributing to reduce the use of coal energy sources and then start to replace them with more environmentally friendly solar energy.
\end{abstract}

Keywords: Content analysis; environmental communication; representation; documentary film; Sexy Killers

Korespondensi: Muhammad Ariq Anhasdio Faiz, S.I.Kom. Universitas Padjadjaran. Jalan Raya BandungSumedang KM. 21, Jatinangor, Sumedang 45363. Surel: muhammad16085@mail.unpad.ac.id 


\section{PENDAHULUAN}

Film adalah serangkaian gambar yang diproyeksikan pada sebuah layar agar tercipta ilusi (tipuan) gerak yang hidup, mempunyai fungsi sebagai penyampaian pesan atau informasi (Urbani \& Purnama, 2011). Selain itu, film adalah sebuah media untuk menampilkan gambar lebih dari satu bingkai sehingga tersusun sebuah makna. Film pun media yang mampu memengaruhi secara efektif pola pikir masyarakat dan banyak menampung ilmu pengetahuan menjadi media yang dapat memengaruhi penerimaan makna penonton dalam suatu hal (Mudjiono, 2011).

Film memiliki berbagai jenis yang disebut dengan genre, misalnya film dokumenter. Film dokumenter adalah dokumentasi dalam bentuk film mengenai suatu peristiwa bersejarah atau suatu aspek seni budaya yang mempunyai makna khusus agar dapat menjadi alat penerang dan alat pendidikan. Pengertian bersejarah ini tidak hanya tentang peristiwa yang mengandung sejarah, tetapi juga mengenai usaha untuk mengusut asal-usul suatu hal. Oleh karena itu, suatu film dokumenter dapat bercerita mengenai berbagai hal dalam upaya menyelidiki sesuatu sehingga dapat menjadi alat penerang (Kemdikbud, 2016).

Di masyarakat terdapat film dokumenter yang mengupas sebuah fenomena sesuai karakteristik di atas, yakni Watchdoc. Kanal ini konsisten mengunggah karya dokumenter di YouTube. Watchdoc berada dalam naungan Dandhy Dwi Laksono yang telah melakukan ekspedisi keliling Indonesia, bernama Ekspedisi Indonesia Biru pada Januari 2015. Ekspedisi ini bertujuan meliput dan mengabadikan kekayaan alam nusantara. Ekspedisi ini menghasilkan sebuah film berjudul Sexy Killers yang dirilis pada April 2019 dan mampu menembus 14 juta penonton dalam 5 hari saja (Natasha, 2019). Sexy Killers mendokumentasikan pengaruh yang ditimbulkan dari penggunaan Pembangkit Listrik Tenaga Uap (PLTU).

Sexy Killers sebagai film dokumenter tidak terlepas dari proses komunikasi visual dalam upaya menyampaikan pesannya. Komunikasi visual merupakan sebuah proses dalam menyampaikan pesan oleh komunikator dan proses dalam penerimaan pesan kepada komunikan dengan memakai simbol-simbol atau lambang-lambang visual (Hansen \& Machin, 2013).

Model dari komunikasi visual adalah komunikasi langsung yang memiliki karakteristik sederhana dan sifatnya satu arah. Produsen sebagai komunikator, memiliki peran dalam menyampaikan ide awal (encoder), membuat pesan yang di dalamnya terdapat elemen visual kepada komunikan (penonton) dengan tujuan komunikan memahami pesan 
yang disampaikan (Sari, 2013). Penonton sebagai komunikan (decoder) merespons dengan cara menginterpretasikan pesan tersebut (Safanayong, 2006).

Komunikasi visual dapat dianalisis dengan fokus mengenai contexts dan sites. Contexts memiliki tiga major contexts: (1) communicative; (2) cultural; dan (3) historical, serta terdapat tiga major sites:(1) production;(2) content; dan (3) consumption, dalam pembuatan sebuah visual yang bermakna. Contexts dan sites dimaknai dalam untuk menganalisis dan memahami cara kerja komunikasi visual, serta untuk mengonseptualisasikan dan memahami peran yang lebih luas dari komunikasi visual dalam kaitannya dengan konstruksi sosial dan politik dari isu lingkungan dan kontroversi di ruang publik (Hansen \& Machin, 2013).

Film dapat dilihat dari dua perspektif, perspektif pertama menyatakan bahwa film memiliki kandungan unsur estetika tinggi. Perspektif kedua menyatakan bahwa film adalah sebuah media komunikasi yang dipakai untuk menyampaikan pesan secara tersebar dari pembuat film kepada publik. Film menitikberatkan pada unsur komunikasi karena film masuk sebagai salah satu bentuk media massa. Dengan demikian, jika seorang pembuat film memproduksi film untuk menyebarkan pesan dari film tersebut, maka pembuat film melakukan kegiatan komunikasi massa
(Permana et al., 2019).

Selain itu, komunikasi massa dapat menghasilkan produk berupa pesan yang dilakukan olehkomunikator yang terlembagakan dengan penyebaran dan pendistribusian kepada khalayak luas. Proses komunikasi massa ini juga memiliki karakteristik yakni timbulnya keserempakan, bersifat satu arah, komunikan yang anonim dan heterogen, serta komunikasi yang mengutamakan isi ketimbang hubungan (Ardianto et al., 2015).

Komunikasi massa memiliki fungsi sosialisasi yang mengacu pada sebuah media massa yang mewakili gambaran masyarakat di mana media massa menampilkan kepada khalayak bagaimana mereka bertindak dan hal apa yang diharapkan oleh mereka (Dominick, 2012). Hal tersebut menunjukkan bahwa media mewakili khalayak dengan model peran yang khalayak amati dan harapkan untuk ditiru.

Perjalanan sejarah film sebagai media massa memiliki 3 aspek penting. Pertama, Film sebagai alat propaganda digunakan secara signifikan. Penggunaan sebagai alat propaganda tersebut didukung oleh kelebihan film yang memiliki jangkauan luas, memberikan dampak emosional, dan sifat yang nyata. Kedua, kemunculan berbagai sekolah seni film. Ketiga, kemunculan gerakan film dokumenter (McQuail, 2012).

Film dokumenter adalah film yang 
pembuatannya didasarkan pada suatu peristiwa sesuai realitas dan fakta yang ada. Film dokumenter tidak diproduksi pada sebuah skenario yang menghasilkan pembuatan adegan berdasarkan pembuat film, melainkan menggunakan hasil olahan penelitian sebagai sebuah konsep dalam film dokumenter tersebut (Karnanta, 2012). Film dokumenter merupakan film yang murni didasarkan pada sebuah fakta dan menampilkan fakta di mana memiliki dasar filosofis yang sama dengan etnografi. Pendekatan film dokumenter berbeda dengan pendekatan pada film fiksi, yang meliputi proses kreatif, segi estetika gambar, dan tujuan pembuatan film tersebut. Film dokumenter juga memiliki elemen realisme yang dimaknai sebagai sebuah aliran kesenian yang berusaha melukiskan sebagaimana nyatanya (McQuail, 2012).

Selain itu, film dokumenter merupakan film yang serius, yakni sebuah film yang berusaha untuk mengajari khalayaknya sesuatu. Secara sederhana film dokumenter ini diartikan sebagai film tentang kehidupan yang sebenarnya (Aufderheide, 2007). Namun hal tersebut menjadi masalah, Aufderheide menjelaskan bahwa:

"[...] documentaries are about real life; they are not real life. They are not even windows onto real life. They are portraits of real life, using real life as their raw material, constructed by artists and technicians who make myriad decisions about what story to tell to whom, and for what purpose"
(Aufderheide, 2007)”

Film dokumenter memiliki subgenre yang menyajikan perbedaan fokus konten yaitu public affairs, government propaganda, advocacy, historical, ethnographic, dan nature. Bagi aktivis maupun pegiat suatu bidang, pemilihan film dengan jenis dokumenter adalah sesuatu yang sering dijumpai karena keberadaan film dokumenter yang menampilkan fakta yang ada sehinggadapatmemberikangambaranyangnyata kepada khalayak jika ingin melakukan sebuah upaya advokasi. Pemilihan film dokumenter bagi upaya advokasi juga disebabkan anggaran yang dibutuhkan cenderung lebih sedikit dalam rangka mempertanyakan dan mengkritisi kebijakan pemerintah maupun pemangku kepentingan yang ada saat ini. Film subgenre advokasi ini biasanya berfokus mengarahkan khalayak dalam tindakan tertentu (Aufderheide, 2007).

PLTU merupakan pembangkit yang menggunakan energi kinetik dari uap untuk menggerakkan generator agar dapat menghasilkan listrik. Sexy Killers menampilkan PLTU di Indonesia menggunakan bahan bakar batu bara untuk menghasilkan uap yang nantinya mengaliri listrik. Data di lapangan menunjukkan sebanyak 58 ribu MW (megawatt) kapasitas pembangkit yang ada di Indonesia, pada 2019 sebanyak 61 persen di antaranya 
masih menggunakan batu bara (Banjarnahor, 2019).

Begitu banyaknya PLTU memberikan konsekuensi terhadap lingkungan sekitar baik secara positif maupun negatif. Dampak unit sosial di antaranya yaitu dampak individu dan dampak masyarakat. Dampak individu terbagi lagi menjadi beberapa bagian yaitu dampak biologis, kenyamanan, dan psikis. Dampak masyarakat terbagi menjadi lingkungan hidup, ekonomi, maupun pendidikan (Prakoso et al., 2016).

Penggunaan sumber energi batu bara sebagai pembangkit listrik dijelaskan pula konsekuensinya sebagaiberikut:(1)dust \& noise, yakni operasi penambangan mengakibatkan adanya debu maupun kebisingan; (2) mine subsidence, dengan penambangan batu bara akan mengakibatkan penurunan muka tanah; (3) pencemaran air, air di sekitar tambang batu bara dapat tercemar oleh tanah hasil pengurukan; dan (4) acid main drainage adalah air kaya logam yang terbentuk dari reaksi kimia. Konsekuensi tersebut menunjukkan berbagai hal yang perlu dikorbankan dalam mengaplikasikan batu bara sebagai sumber energi pembangkit listrik bertenaga uap (World Coal Association, 2020). Aktivitas PLTU memiliki konsekuensi, salah satunya adalah polusi udara. Emisi PLTU dengan bahan bakar batu bara menyumbang sebanyak 20-30 persen polusi udara hanya di
Jakarta saja (CNN Indonesia, 2019).

PLTU merupakan sistem pembangkitan tenaga listrik menggunakan bahan bakar batu bara (Tumbol, 2015). PLTU tidak hanya dapat menggunakan bahan bakar batu bara, tetapi juga dapat menggunakan bahan bakar lain yaitu minyak. Minyak sebagai bahan bakar PLTU cenderung memiliki pembuangan gas yang lebih bersih dibandingkan PLTU berbahan bakar batu bara.

Batu bara sendiri merupakan bahan bakar pembangkit listrik paling banyak digunakan di Indonesia. Berdasarkan 58 ribu MW (megawatt) kapasitas pembangkit, pada tahun 2019 sebanyak 61 persen di antaranya masih menggunakan batu bara (Banjarnahor, 2019).

PLTU memiliki kelebihan dan kekurangan (Tumbol, 2015). Kelebihan penggunaan PLTU yaitu: (1) efisiensi tinggi dengan metode Waste Heat Utilization; (2) hasil pembangkitan uap dapat digunakan untuk proses produksi Mill; (3) biaya bahan bakar lebih murah; dan (4) biaya pemeliharaan lebih murah. Adapun kekurangan penggunaan PLTU yakni: (1) membutuhkan penanganan air umpan yang akan masuk ke dalam boiler; (2) menghasilkan limbah batu bara yang memerlukan penanganan khusus; (3) menghasilkan polutan yang lebih tinggi; (4) membutuhkan area yang lebih luas; dan (5) kurang responsif terhadap fluktuasi.

PLTU sendiri, hanya di Jakarta saja yang 
$\mathbf{0}$

\subsection{1}

Sumber: Katadata.co.id, 2016
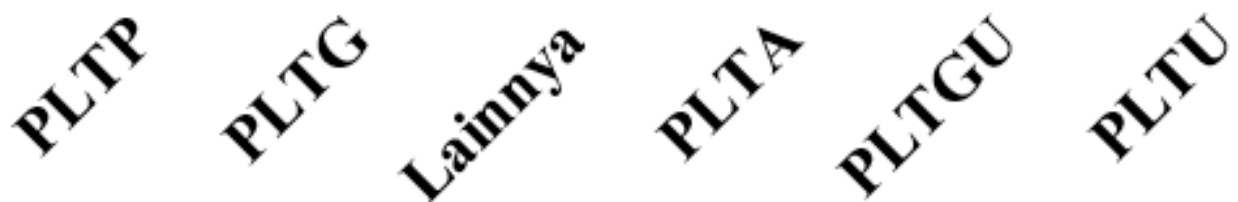

\section{MW (megawatt)}

Gambar 1 Kapasitas Pembangkit Terpasang Menurut Jenisnya pada 2015 Data dari PT (Persero) PLN

menyumbang 20-30 persen polusi udara (CNN Indonesia, 2019). PLTU di Jakarta terdapat 10 yang menggunakan sumber energi batu bara dan menyumbangkan polusi. Selain itu, di seluruh Indonesia sendiri terdapat 4 PLTU yang termasuk PLTU terbesar dengan menyumbang kapasitas produksi total lebih dari $10.000 \mathrm{MW}$ yakni, PLTU Paiton Swasta I dan II, PLTU Suralaya, PLTU Cirebon, dan PLTU Batang. Berbagai PLTU tersebut menyumbang dampak berbagai jenis (Prakoso et al., 2016).

Dampak dalam unit sosial individu yakni biologis adalah dampak pada kesehatan berupa batuk berdahak, kulit kering, dan gatal-gatal. Selain itu juga terdapat pengaruh terhadap kenyamanan yang ditimbulkan oleh kebisingan mesin PLTU serta perubahan suasana menjadi panas. Di samping dampak unit sosial individu ini, terdapat dampak unit sosial masyarakat berupa dampak lingkungan hidup yang mengakibatkan air, udara, dan tanah yang tercemar.

Dampak pembanugnan PLTU juga dapat berupa kerugian terhadap suatu profesi yang ada di kawasan tersebut. Salah satunya keberadaan PLTU Batang yang membuat rugi para nelayan karena terganggunya ekosistem laut sehingga tidak dapat mencari ikan serta hewan laut lainnya (Pramanik et al., 2020).

Sebagai film dokumenter yang membahas isu lingkungan terkait PLTU, film ini dapat dikaitkan dengan komunikasi lingkungan. Komunikasi lingkungan merupakan sebuah bentuk ekspresi pragmatis dan pokok dalam hubungan ekologis di dunia, termasuknonhuman systems, elemen, dan spesies (Pezzullo \& 
Cox, 2018). Komunikasi lingkungan terbagi dalam dua fungsi, yaitu fungsi pragmatis dan fungsi constitutive. Fungsi pragmatis merupakan sebuah bentuk interaksi baik verbal maupun nonverbal yang membawa suatu tujuan seperti informasi dan edukasi. Adapun fungsi constitutive adalah bentuk interaksi yang membentuk, mengorientasikan, dan menegosiasikan makna, nilai, dan hubungan.

Komunikasi lingkungan memiliki bentuk advokasi lingkungan sebagai tindakan dalam mewujudkan komunikasi lingkungan ini. Advokasi dalam komunikasi lingkungan adalah bagian dari dukungan pada sebuah tujuan, kebijakan, ide, atau serangkaian nilai tertentu. Ada dua bagian besar dari advokasi lingkungan yakni advocacy campaigns dan critical rhetoric. Advocacy campaigns adalah tindakan strategis terorganisasi yang melibatkan komunikasi dalam mencapai tujuan yang lebih besar dan critical rhetoric adalah suatu tindakan yang mempertanyakan dan/atau mengkritisi status $q u o$ (kebijakan saat ini).

Proses komunikasi dapat berperan untuk memotivasi perilaku yang bertanggung jawab terhadap lingkungan. Lebih lanjut lagi, semakin seseorang bergantung pada media, atau ketergantungan media, maka akan dapat memotivasi perubahan perilaku (Ho et al., 2015).

Komunikasi lingkungan adalah sebuah perencanaan dan strategi melalui proses komunikasi dan produk media untuk mendukung pembuatan kebijakan yang efektif, partisipasi publik, dan implementasi yang berkelanjutan pada lingkungan. Komunikasi lingkungan juga merupakan komunikasi yang memberikan informasi tentang upaya dalam rangka mengurangi beban lingkungan dan mempromosikan pelestarian lingkungan. Oleh karena itu, komunikasi lingkungan merupakan strategi dan alat yang penting dan sangat diperlukan untuk mengatasi masalah lingkungan (Zikargae, 2018).

Komunikasi lingkungan ialah bentuk ekspresi pragmatis dan pokok dalam hubungan ekologis di dunia, termasuk dalam nonhuman systems, elemen, dan spesies. Komunikasi lingkungan terbagi ke dalam dua fungsi. Pertama, fungsi pragmatic sebagai bentuk interaksi verbal dan nonverbal yang membawa suatu tujuan seperti informasi dan edukasi. Fungsi pragmatis tampak contohnya ketika suatu organisasi pro lingkungan yang mengedukasi kepada masyarakat dan mengerahkan dukungan publik terhadap suatu permasalahan lingkungan melalui iklan televisi dengan kampanye "clean coal". Kedua, fungsi constitutive yang merujuk pada keharusan mengandung interaksi verbal dan nonverbal yang membentuk, mengorientasikan, dan menegosiasikan makna, nilai, dan hubungan (Pezzullo \& Cox, 2018). 
Komunikasi merupakan aspek penting dalam penyelamatan lingkungan karena terdapat bagian ilmu dalam komunikasi yang digunakan sebagai penyokong utama penyelamatan lingkungan dengan segala isinya (Yenrizal, 2017). Usaha komunikasi dalam rangka melestarikan lingkungan (alam) merupakan hal yang penting sebagai tujuan bersama dalam penyelesaian sebuah permasalahan. Selain itu, perlu adanya ambisi dan kerja sama berbagai pihak mulai dari pemangku kepentingan, pemerintah, pengusaha, masyarakat, dan media sebagai upaya menjaga alam yang lestari (Kadarisman, 2019).

Fungsi komunikasi lingkungan merupakan salah satu faktor utama dalam rangka menjaga keserasian alam. Langkah nyata dari fungsi komunikasi lingkungan adalah mengajak khalayak untuk menurunkan tingkat dari polusi udara sebagai ambisi pencegahan pemanasan global, membuang limbah pabrik, pertanian, dan rumah tangga pada tempat yang semestinya dan tidak ke laut, dan sebagainya (Kadarisman, 2019).

Komunikasi lingkungan memiliki sebuah bentuk tindakan yang dikenal sebagai advokasi. Advokasi dalam komunikasi lingkungan ini merupakan bentuk tindakan komunikasi untuk mendukung sebuah tujuan, kebijakan, ide, atau serangkaian nilai tertentu. Advokasi lingkungan ini dapat berbeda dari tujuannya, media yang digunakan, dan target khalayak. Advokasi lingkungan ini terbagi menjadi dua bentuk yang luas yaitu advocacy campaigns dan critical rhetoric. Kedua bentuk tersebut adalah dua hal yang berbeda namun keduanya dapat saling melengkapi. Suatu waktu sebelum kampanye advokasi lingkungan dimulai, terdapat sebuah periode di mana kebijakan saat ini (status quo) dipertanyakan dan ambisi untuk menemukan cara yang lebih baik diungkapkan. Pada masa tersebutlah critical rhetoric berperan (Pezzullo \& Cox, 2018).

"Critical rhetoric is the questioning or criticism of a policy, societal value, or ideology. Such rhetoric may also articulate an alternate policy, vision, or ideology. Throughout the modern environmental movement, many voices have questioned or criticized the taken-for-granted views of culture" (Pezzullo \& Cox, 2018).

Dengan demikian, advocacy campaigns berbeda dengan critical rhetoric. Di mana advocacy campaigns lebih menitikberatkan pada usaha untuk meraih sesuatu dengan tujuan yang spesifik dalam waktu yang terjadwal yang disegmentasikan pada khalayak tertentu. Penggunaan teori komunikasi lingkungan pada penelitian ini bertujuan agar ke depannya kita paham bagaimana fungsi komunikasi lingkungan diaplikasikan pada adegan sebuah film dan paham bagaimana penggunaan critical rhetoric dalam adegan yang ada.

Sexy Killers sebagai film dokumenter 
dijadikan sebagai objek penelitian karena film dokumenter ini telah ditonton sebanyak 29.946.897 kali terhitung pada 9 Maret 2020 dan bahasan di film ini dapat dikaitkan dengan sebuah kegiatan menyangkut komunikasi lingkungan karena membahas tentang dampak terhadap lingkungan (Watchdoc Image, 2019). Penelitian ini meneliti isi pesan yang disampaikan oleh sebuah film dengan tujuan menghasilkan penelitian yang objektif tanpa ada bias penelitian. Hasil penelitian ini diharapkan dapat diketahui bagaimana representasi pesan dampak PLTU yang dikomunikasikan oleh pembuat film Sexy Killers.

Peneliti melakukan peninjauan terhadap penelitian-penelitian sebelumnya sebagai referensi untuk melakukan penelitian dengan menggunakan metode penelitian analisis isi kuantitatif. Karya ilmiah yang peneliti jadikan rujukan adalah sebagai berikut.

Pertama, penelitian mengenai isi pesan nasionalisme dalam film Merah Putih. Metode yang dipakai adalah analisis isi dengan pendekatan kuantitatif tipe deskriptif (Akbar et al., 2017). Penelitian tersebut dijadikan rujukan sebagai referensi mengenai penelitian metode analisis isi kuantitatif deskriptif dengan objek penelitian berupa film yang populasinya merupakan adegan dari sebuah film. Adapun yang membedakan dengan penelitian ini adalah film yang diteliti dan konseptualisasi yang digunakan.

Kedua, penelitian mengenai kritik sosial dalam film dokumenter Belakang Hotel. Hasil dari penelitian ini menunjukkan aspek tindakan komunikatif menempati urutan tertinggi dengan Comprehensibility 33 persen kemudian aspek tindakan strategis mendapatkan 18,9 persen, dan terakhir adalah aspek Lebenswelt (DuniaKehidupan) mendapat 4,7 persen (Kurniawan, 2015).

Kaitan skripsi tersebut dengan penelitian penelitiadalah kesamaan metode penelitian yang digunakan. Selain itu, terdapat kesamaan dalam objek penelitian yakni genre film dokumenter. Perbedaan dengan penelitian peneliti yakni film yang diteliti dan konseptualisasi yang digunakan.

Ketiga, penelitian mengenai isu, ekspresi pesan, argumentasi, sisi argumentasi, tendensi, dan format pesan dalam buletin Dakwah Kaffah (Firdaus, 2018). Penelitian ini menggunakan metode analisis isi kuantitatif pendekatan deskriptif. Hasil penelitian menunjukkan buletin terbitan Hizbut Tahrir Indonesia dengan judul Dakwah Kaffah ini paling sering membahas tema agama. Ekspresi pesan mengenai khilafah banyak disampaikan dengan cara eksplisit. Tipe argumentasi yang dipakai seluruhnya adalah tipe argumentasi keagamaan. Sisi pesan paling banyak disampaikan dalam satu sisi. Tendensi positif paling banyak muncul dalam buletin 
tersebut. Format pesan yang paling banyak muncul adalah yang bersifat persuasif.

Kontribusi penelitian berupa skripsi tersebut adalah sebagai referensi peneliti untuk menggunakan variabel yang digunakan dalam analisis isi kuantitatif yakni variabel sisi pesan dan tendensi pesan. Adapun perbedaan penelitian tersebut dengan penelitian peneliti adalah objek penelitian yang diteliti dan konseptualisasi yang digunakan.

Penelitian ini memiliki kebaruan berupa pemakaian teori komunikasi lingkungan untuk mengetahui representasi pesan lingkungan dalam sebuah film dokumenter. Dengan demikian, penelitian ini bertujuan untuk mengetahui bagaimana representasi dampak penggunaan pembangkit listrik tenaga uap terhadap lingkungan dalam film Sexy Killers melalui dampak, pesan, tendensi pesan, fungsi komunikasi lingkungan, dan critical rhetoric dalam merepresentasikan dampak penggunaan PLTU terhadap lingkungan film dokumenter Sexy Killers.

Dampak unit sosial sebagai variabel 1 dalam penelitian ini memiliki dua buah sub variabel yaitu individu dan masyarakat. Dua dampak unit sosial tersebut diukur dengan skala nominal inklusif (Prakoso et al., 2016). Pada dampak unit sosial individu, indikator berupa 1 (biologis), 2 (kenyamanan), dan 3 (psikis). Dampak unit sosial masyarakat, indikatornya berupa 1 (lingkungan hidup), 2 (pendidikan), dan 3 (ekonomi).

Sisi pesan sebagai variabel 2 memiliki dua buah sub variabel yaitu satu sisi pesan dan dua sisi pesan. Sisi pesan merupakan salah satu elemen penyampaian pesan yang memberikan keterangan apakah komunikator menyampaikan hanya satu sisi saja atau justru dua sisi (Venus, 2018).

Variabel 3 adalah tendensi pesan yang menunjukkan apakah komunikator menyampaikan pesan yang condong ke arah positif, negatif, atau netral. Sub variabel positif dimaknai jika pesan yang disampaikan komunikator di dalamnya mengandung unsur pujian, menonjolkan kelebihan, dan pendapat positif. Adapun sub variabel negatif mengandung unsur pesan protes, keluhan, sindiran, dan pendapat negatif. Sub variabel netral jika pesan tidak condong pada sebuah makna positif atau negatif (Ratnasari, 2010).

Fungsi komunikasi lingkungan adalah variabel 4 dari penelitian ini. Variabel fungsi komunikasi lingkungan mengandung dua sub variabel yaitu pragmatic (pragmatis) dan constitutive (pokok) (Pezzullo \& Cox, 2018). Dua fungsi komunikasi lingkungan ini diukur dengan skala nominal berupa 1 (ada) dan 0 (tidak ada). Variabel 4 pada penelitian ini akan menggambarkan fungsi komunikasi lingkungan apa yang ditunjukkan pada setiap adegan yang 
diteliti.

Variabel 5 adalah penggunaan advokasi lingkungan dengan bentuk critical rhetoric (Pezzullo \& Cox, 2018). Variabel ini langsung mengategorikan adegan apakah terdapat penggunaan critical rhetoric atau tidak sehingga pengukurannya menggunakan skala nominal berupa 0 (tidak ada) dan 1 (ada). Variabel 5 akan menunjukkan penggunaan critical rhetoric dalam film.

Dengan demikian, penelitian ini bertujuan untuk mengetahui bagaimana representasi dampak penggunaan pembangkit listrik tenaga uap terhadap lingkungan dalam film Sexy Killers melalui dampak, pesan, tendensi pesan, fungsi komunikasi lingkungan, dan critical rhetoric dalam merepresentasikan dampak penggunaan PLTU terhadap lingkungan film dokumenter Sexy Killers.

\section{METODE PENELITIAN}

Penelitian ini menggunakan pendekatan kuantitatif melalui metode penelitian deskriptif. Pendekatan deskriptif bertujuan memberikan gambaran (mendeskripsikan) secara rinci suatu pesan atau suatu teks tertentu dan karakteristiknya (Eriyanto, 2011). Peneliti menganalisis isi untuk mendeskripsikan pesan dengan menggunakan aliran transmisi yang artinya meneliti pesan yang disampaikan pengirim kepada khalayak (Eriyanto, 2011).
Peneliti tidak meneliti makna di balik pesan yang disampaikan pembuat film karena film ini mengandung paradigma produksi dan pertukaran makna.

Analisis isi deskriptif merupakan analisis yang meneliti terhadap makna dan isi konstektual dari bahasa sebagai komunikasi (Akbar et al., 2017). Analisis isi memiliki tujuan untuk mengukur secara objektif dengan menghindari bias dari subjek penelitian dan menggambarkan karakteristik sebuah isi yang dilakukan secara sistematis yang tampak serta dilakukan secara objektif, valid, reliabel, dan mudah dilakukan direplikasi.

Teknik pengumpulan data pada penelitian analisis ini didapatkan dengan dua cara yaitu sebagai berikut. Pertama, observasi yang dilakukan adalah observasi non partisipan dengan cara menyaksikan film dan memahami isi pesan dari film Sexy Killers. Proses memahami isi pesan merupakan proses untuk mengetahui suatu adegan dalam film secara eksplisit yang berbicara tentang apa, tanpa mencari makna di balik setiap adegan dari film tersebut. Hal selanjutnya adalah peneliti menemukan pesan yang kemudian dikategorikan pada kategorisasi penelitian; Kedua, studi literatur dilakukan untuk mengumpulkan berbagai data yang dibutuhkan berupa penelaahan terkait komunikasi lingkungan dan film dokumenter Sexy Killers. ketiga, dokumentasi film Sexy 
Tabel 1 Operasionalisasi Variabel

\begin{tabular}{|c|c|c|}
\hline Variabel & Sub variabel & Indikator \\
\hline \multirow{2}{*}{$\begin{array}{c}\text { Dampak Unit } \\
\text { Sosial }\end{array}$} & Individu & $\begin{array}{l}\text { Penyebutan } \\
\text { dampak terhadap } \\
\text { individu. }\end{array}$ \\
\hline & Masyarakat & $\begin{array}{l}\text { Penyebutan } \\
\text { dampak } \\
\text { terhadap lingkup } \\
\text { masyarakat. }\end{array}$ \\
\hline \multirow[t]{2}{*}{ Sisi Pesan } & Satu sisi & $\begin{array}{l}\text { Penyampaian } \\
\text { pesan hanya satu } \\
\text { sisi pada sebuah } \\
\text { adegan. }\end{array}$ \\
\hline & Dua sisi & $\begin{array}{l}\text { Penyampaian } \\
\text { pesan dua sisi } \\
\text { pada adegan. }\end{array}$ \\
\hline \multirow{3}{*}{ Tendensi } & Positif & $\begin{array}{l}\text { Penyampaian } \\
\text { dampak positif } \\
\text { pada adegan. }\end{array}$ \\
\hline & Negatif & $\begin{array}{l}\text { Penyampaian } \\
\text { dampak negatif } \\
\text { pada adegan. }\end{array}$ \\
\hline & Netral & $\begin{array}{l}\text { Penyampaian } \\
\text { dampak yang } \\
\text { tidak mengarah } \\
\text { pada positif } \\
\text { maupun negatif. }\end{array}$ \\
\hline \multirow{3}{*}{$\begin{array}{l}\text { Fungsi } \\
\text { Komunikasi } \\
\text { Lingkungan }\end{array}$} & Pragmatic & $\begin{array}{l}\text { Penggunaan } \\
\text { interaksi verbal } \\
\text { dan nonverbal } \\
\text { yang membawa } \\
\text { suatu tujuan } \\
\text { seperti informasi } \\
\text { dan edukasi. }\end{array}$ \\
\hline & Constitutive & $\begin{array}{l}\text { Penggunaan } \\
\text { interaksi verbal } \\
\text { dan nonverbal } \\
\text { yang membentuk, } \\
\text { mengorientasikan, } \\
\text { dan } \\
\text { menegosiasikan } \\
\text { makna, nilai, dan } \\
\text { hubungan. }\end{array}$ \\
\hline & Critical Rhetoric & $\begin{array}{l}\text { Mempertanyakan } \\
\text { atau mengkritisi } \\
\text { sebuah tindakan, } \\
\text { aturan, nilai sosial, } \\
\text { dan/atau ideologi. }\end{array}$ \\
\hline
\end{tabular}

Sumber: Hasil Penelitian, 2020

Killers yang ditayangkan di YouTube kanal Watchdoc Image. Film tersebut diunggah pada 13 April 2019.

Uji reliabilitas dalam penelitian ini menggunakan formula yang dikemukakan oleh Krippendorff yakni Formula Krippendorff Alpha (Eriyanto, 2011). Huruf $p f u$ merupakan penjumlahan frekuensi dari unityang mengalami ketidaksetujuan, pmt adalah penjumlahan dari total marginal, $n$ adalah jumlah unit yang dicoding, dan $m$ adalah jumlah coder.

Penelitian dengan metode analisis isi membutuhkan coder sehingga dalam penelitian ini sehingga peneliti menggunakan minimal dua coder untuk menghasilkan penelitian yang valid dan reliabel. Peneliti menentukan kriteria untuk coder yaitu, coder paham tentang analisis isi, coder mengerti tentang film dokumenter, dan coder paham tentang PLTU.

Tabel 2 Hasil Uji Reliabilitas Antar-Coder

\begin{tabular}{lll}
\hline Variabel & Sub variabel & $\begin{array}{l}\text { Krippendorff's } \\
\text { Alpha }\end{array}$ \\
\hline \multirow{2}{*}{ Dampak } & Unit Sosial Individu & 0,866 \\
\cline { 2 - 3 } & $\begin{array}{l}\text { Unit Sosial } \\
\text { Masyarakat }\end{array}$ & 0,915 \\
\hline Sisi Pesan & & 0,891 \\
\hline Tendensi Pesan & & 0,894 \\
\hline \begin{tabular}{l} 
Fungsi $\begin{array}{l}\text { Komunikasi } \\
\text { Lingkungan }\end{array}$ \\
\cline { 2 - 3 } Critical Rhetoric
\end{tabular} & Constitutive & 0,815 \\
\hline
\end{tabular}

Sumber: Hasil Penelitian, 2020

Selain pemberian kriteria untuk coder, peneliti juga memberikan pelatihan bagi coder dengan tujuan memberikan pemahaman dan pengertian tentang penelitian ini sehingga mampu menganalisis dengan baik. Coder dalam penelitian ini yakni sebanyak tiga coder yang terdiri atas penulis dan dua mahasiswa Program 
Studi Televisi dan Film Universitas Padjadjaran.

Hasil reliabilitas antar coder memiliki batas bawah yaitu 0,800 . Hal ini berdasarkan pernyataan Krippendorff yang menyatakan data adalah reliabel jika menghasilkan angka lebih dari sama dengan 0,800 (Krippendorff, 2018).

\section{HASIL DAN PEMBAHASAN}

Hasil penelitian menunjukkan Sexy Killers memunculkan berbagai dampak dari penggunaan PLTU. Representasi pesan lingkungan digambarkan dengan berbagai penjelasan dampak negatif baik terhadap unit sosial individu maupun masyarakat. Hasil penelitian dari setiap variabel dijabarkan dalam gambar frekuensi berdasarkan variabel yang ada (Gambar 2).

Dampak biologis ditunjukkan dalam adegan 32. Adegan 32 menyatakan bahwa adanya masalah kesehatan terhadap individu tersebut (Prakoso et al., 2016).

"PLTU ini memasok sebagian kebutuhan listrik di Kota Palu dan Donggala. Meski kapasitasnya kecil, bagi keluarga Arsyad yang berjarak 100 meter dari pagar PLTU dampaknya sangat serius" (Laksono \& Arz, 2019).

Kemudian, Arsyad menyampaikan pernyataan berikut.

"Hasil rontgen mengatakan bahwa saya termasuk menderita alergi debu, kalau bicara tentang debu tidak ada debu lain di sini, Pak, karena rumah kami jauh dari jalan raya. Debu yang kami rasakan kalo alergi debu ya debu PLTU saja, Pak." (Laksono \& Arz, 2019)

Selanjutnya, adegan tentang dampak kenyamanan yang menjelaskan bahwa adanya PLTU membuat kebutuhan listrik masyarakat terpenuhi. Hal tersebut memberikan kejelasan bahwa PLTU memberikan dampak kenyamanan

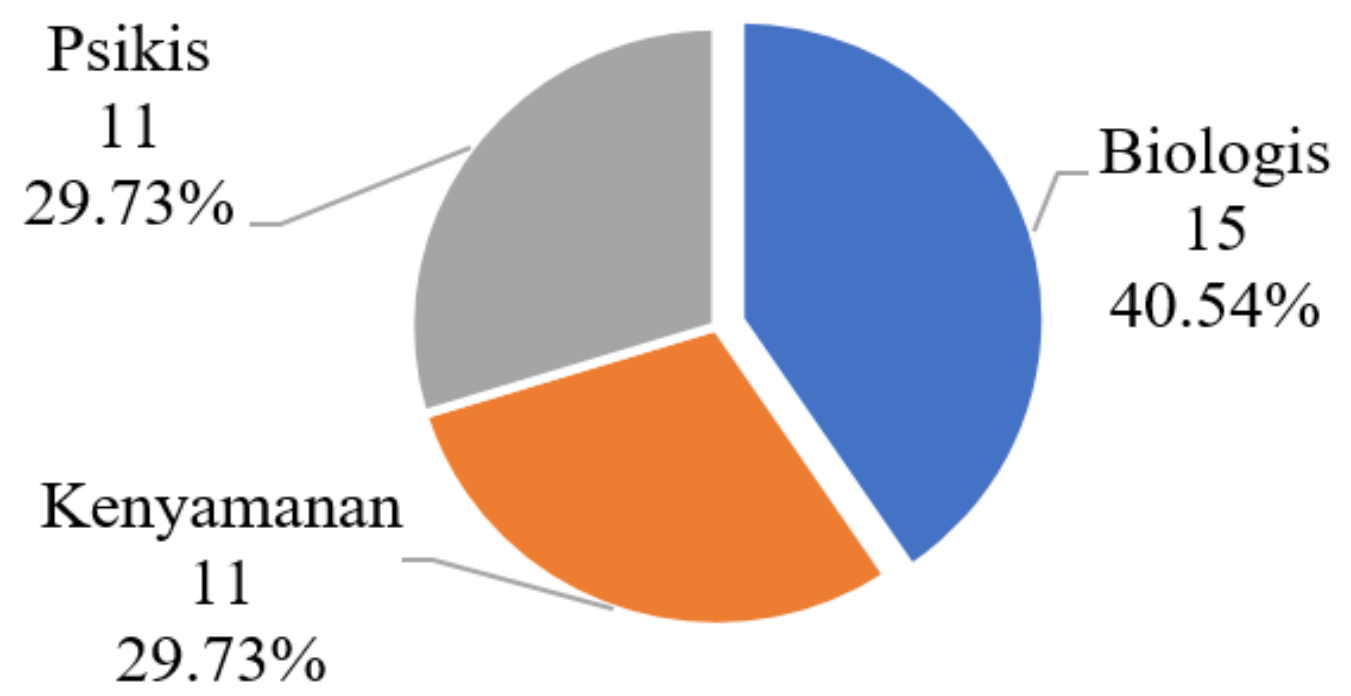

Sumber: Hasil Penelitian, 2020

Gambar 2 Frekuensi Dampak Unit Sosial Individu

Representasi pesan lingkungan dalam Sexy Killers 
bagi unit sosial individu berupa listrik yang memadai (Prakoso et al., 2016).

Dampak psikis dalam unit sosial individu ditunjukkan dalam adegan 23 pada 39.43. Dampak psikis muncul karena adanya penjelasan individu yang berpeluang kehilangan pekerjaan (Prakoso et al., 2016).

"Di Cirebon, Jawa Barat, PLTU juga bersinggungan dengan petani garam. PLTU berkapasitas 600 megawatt ini dimiliki oleh Indika Energy yang juga memiliki tambang batu bara dan sedang membangun tambahan 1000 megawatt." (Laksono \& Arz, 2019)

"Petani: Ya mau digusur kata saya tuh ya jangan ini kan penghasilannya tetap kan kalau itu kan katanya bilangnya program pemerintah. Ya (katanya) itu kan untuk kepentingan semua." (Laksono \& Arz, 2019)

Dampak terhadap unit sosial masyarakat yang termasuk kategori lingkungan hidup adalah adegan 26 pada menit 48.01. Dampak tersebut ditunjukkan dengan adanya kerusakan lingkungan sekitar akibat hadirnya PLTU (Prakoso et al., 2016).

"Batu bara yang dibakar untuk diambil panas dan uapnya mengeluarkan zat sisa pembakaran di udara. Sisa pembakaran ini akan menyebar ke tanaman, perairan, atau masuk ke paru-paru seseorang. Teorinya semua ini telah disaring sehingga asap yang keluar konon tidak berbahaya. Tapi teori bisa berbeda dengan kenyataan. Polutan ini mengandung senyawa berbahaya seperti merkuri dan senyawa lain yang disebut PM2.5.

Partikel ini bertahan di udara dalam jangka panjang dan bisa terbang ratusan kilometer. Jika manusia terpapar merkuri atau PM2.5 terusmenerus, akan timbul asma, infeksi saluran pernapasan, hingga kanker paru-paru, bahkan kerusakan otak, ginjal, dan jantung. Menurut penelitian yang dilakukan Greenpeace, polusi udara dari PLTU Celukan Bawang akan memengaruhi ekosistem lumba-lumba di Lovina hingga Taman Nasional Bali Barat. Tentu saja berikut 650 ribu jiwa populasi manusia yang mendiami kawasan ini.”(Laksono \& Arz, 2019)

Sisa adegan menunjukkan dampak terhadap unit sosial masyarakat terkait dengan ekonomi yakni sebanyak 11 dampak ekonomi adegan atau 29,7 persen. Adegan film Sexy Killers tidak ada satu pun yang membicarakan dampak tentang pendidikan.

Salah satu adegan yang membicarakan pendidikan dalam adegan 24 pada menit 46.24. Adanya penurunan terhadap pendapatan masyarakat menunjukkan PLTU memengaruhi ekonomi sekitar yang dapat mengganggu berbagai komponen mata pencaharian (Prakoso et al., 2016).

"Tak hanya nelayan, petani kelapa yang bertetangga dengan PLTU juga punya persoalan sendiri. Untuk membangun pabrik tahap dua, rumah, pekarangan, dan kebun warga telah dibebaskan [...] di antara yang bertahan adalah sepetak kebun kelapa milik Ketut Mangku Wiyana. Penanya: Apa hubungannya PLTU dengan kualitas kelapa Bapak sekarang? Ketut: Kalau hubungan PLTU dengan kualitas kelapa, sudah menurun buahnya dari segi jumlah karena setelah operasinya PLTU 


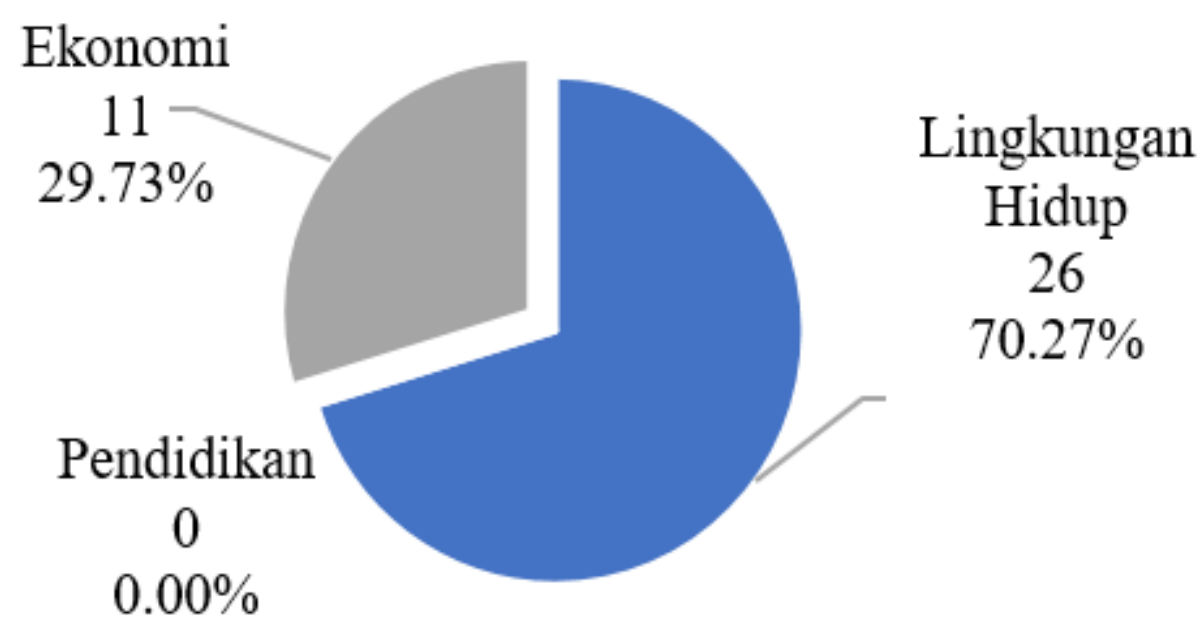

Sumber: Hasil Penelitian, 2020

Gambar 3 Frekuensi Dampak Unit Sosial Masyarakat

ini termasuk juga kecil buahnya sekarang. Narator: Ketut Mangku sebelumnya mampu mendapatkan 9 ribu butir kelapa setiap kali panen, namun kini ia mengaku hanya dapat memanen 2500 butir saja. Ketut: Yang jelas dengan adanya pembangunan, perubahan ada. Tidak mungkin tidak ada. Ada perubahannya [...] Sekarang itu contohnya ada tuh mati janur yang masih ada. Kalau dimakan kuman kan berarti janurnya. Itu ada janurnya yang sebelahnya sudah coklat itu" (Laksono \& Arz, 2019).

Sexy Killers banyak menyampaikan pesan satu sisi yang terdapat dalam 34 adegan atau sebanyak 92 persen dari total adegan dampak. Satu sisi pesan artinya tidak menampilkan sudut pandang lain dari fakta yang disampaikan (Venus, 2018). Sexy Killers menyampaikan pesan dampak yang termasuk dalam dua sisi pesan hanya dalam 3 adegan.

"Pasangan ini memilih bertahan dan tidak melepas rumah, pekarangan, serta kebunnya. Namun pilihan ini bukannya tanpa konsekuensi. Surat keterangan dokter ini menyatakan bahwa Surayah atau yang biasa dipanggil Nenek Karimun, menderita batuk menahun atau bronkitis kronis akibat alergi debu." (Laksono \& Arz, 2019)

Kecondongan pesan negatif salah satunya ditunjukkan dalam adegan 30 pada menit 53.28 karena adegan yang menampilkan keburukan dari hadirnya PLTU (Ratnasari, 2010). Adegan ini menjadi bentuk protes terhadap kehadiran PLTU khususnya yang berdekatan dengan permukiman yang mana berdampak pada kesehatan masyarakat.

Satu adegan netral yaitu adegan 28 pada menit 49.37. Adegan ini membicarakan tentang penggunaan panel surya yang secara eksplisit tidak menampilkan kekurangan atau kelebihan penggunaan PLTU sehingga tidak terkategori sebagai kecondongan positif ataupun negatif (Ratnasari, 2010).

Fungsi komunikasi lingkungan dalam film Sexy Killers salah satunya ditunjukkan dalam 


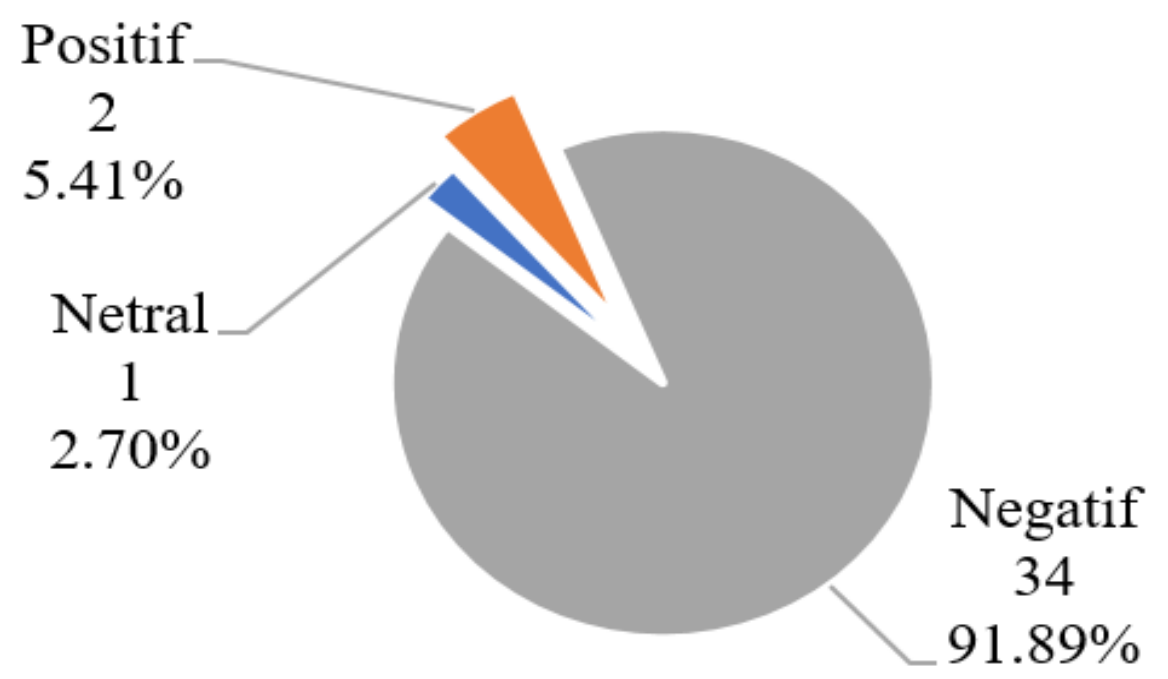

Sumber: Hasil Penelitian, 2020

\section{Gambar 4 Frekuensi Tendensi Pesan}

adegan 41 pada timecode 01.15.45. Adegan tersebut terdapat visualisasi yang menuntun secara praktis untuk menyelamatkan lingkungan dengan tidak menggunakan pembangkit listrik dari sumber energi yang merusak lingkungan yakni batu bara. Tulisan "CORAL NOT COAL" pada tongkang menginformasikan dampak, baik langsung maupun tidak langsung terhadap biota laut dengan menggunakan energi batu bara (Pezzullo \& Cox, 2018).

Contoh adegan yang termasuk fungsi komunikasi lingkungan constitutive adalah adegan 32 pada menit 55.38. Sebagaimana definisi dari fungsi constitutive, adegan ini mengarahkan kesadaran bahwa sumber energi yang digunakan pembangkit listrik tidak ramah lingkungan menyebabkan gangguan kesehatan kepada masyarakat di sekitar.

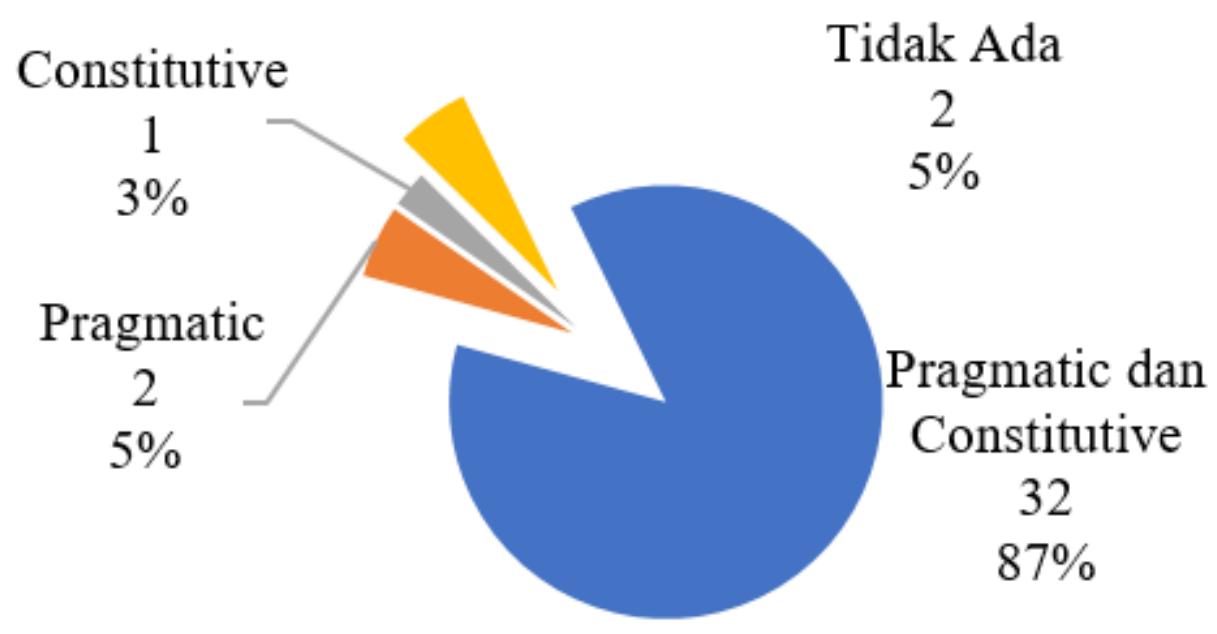

Sumber: Hasil Penelitian, 2020

Gambar 5 Frekuensi Komunikasi Lingkungan

Representasi pesan lingkungan dalam Sexy Killers 
Adegan Sexy Killers yang termasuk dalam bentuk critical rhetoric terdapat dalam adegan 38. Narasinya sebagai berikut.

"[...] lantas mengapa batu bara paling murah? Jawaban singkatnya karena ongkos lingkungan, sosial ekonomi, dan bahkan keselamatan umum, serta kesehatan masyarakat dibebankan kepada mereka yang terdampak" (Laksono \& Arz, 2019).

Visual adegan juga menampilkan keadaan lingkungan di sekitar tempat penambangan batu bara, korban akibat debu PLTU, dan nelayan yang pendapatannya terdampak akibat PLTU. Kebijakan penggunaan batu bara dinilai memberikan dampak negatif yang besar terhadap lingkungan sekitar. Hal tersebut merupakan bentuk critical rhetoric yang tindakannya mengkritisi kebijakan penggunaan batu bara sebagai sumber energi pembangkit listrik dan penggunaan PLTU (Pezzullo \& Cox, 2018).

Film tidak dapat lepas dari kaitannya sebagai media massa. Film sebagai media massa memiliki fungsi informatif, begitu pula dalam film Sexy Killers. Fungsi informatif adalah sebagai sarana menyebarkan informasi dan media publikasi (Permana et al., 2019)7 million audiences. These films increased the hopes for national films. Non-commercial films had also arisen such as Daun di Atas Bantal, Pasir Berbisik, and others. The enthusiasm of independent (indie. Sama halnya dengan film dokumenter Sexy Killers yang menginformasikan bahwa hingga tahun 2027 sebanyak 54,4 persen sumber energi sebagai pembangkit listrik yang digunakan oleh Indonesia adalah energi batu bara. Meskipun hal tersebut lebih tepatnya adalah target bauran energi pembangkitan akhir tahun 2025 dalam RUPTL 2018 sampai dengan 2027 (Keputusan Menteri ESDM Republik Indonesia Nomor 1567 Tentang Pengesahan Rencana Usaha Penyediaan Tenaga Listrik PT Perusahaan Listrik Negara (Persero) Tahun 2018 s.d. 2027, 2018). Sedangkan proyeksi hingga tahun 2027 justru lebih besar yakni 58,6 persen seperti yang dicantumkan dalam Keputusan Menteri ESDM RI No. 1567 tentang Pengesahan RUPTL PT PLN (Persero) tahun 2018 s.d. 2027 berikut ini. "Komposisi produksi energi listrik per jenis energi primer Indonesia diproyeksikan pada tahun 2027 akan menjadi $58,6 \%$ batu bara, 20,6\% gas alam (termasuk LNG), 9,8\% panas bumi, 9,3\% tenaga air, $0,4 \%$ BBM dan 1,3\% EBT lainnya." (Keputusan Menteri ESDM Republik Indonesia Nomor 1567 Tentang Pengesahan Rencana Usaha Penyediaan Tenaga Listrik PT Perusahaan Listrik Negara (Persero) Tahun 2018 s.d. 2027, 2018)

Selain itu, komunikasi massa memiliki fungsi sosialisasi pada tindakan konkret sebuah media massa yang mewakili gambaran masyarakat dengan menampilkan kepada khalayak bagaimana mereka bertindak dan hal apa yang diharapkan oleh mereka 


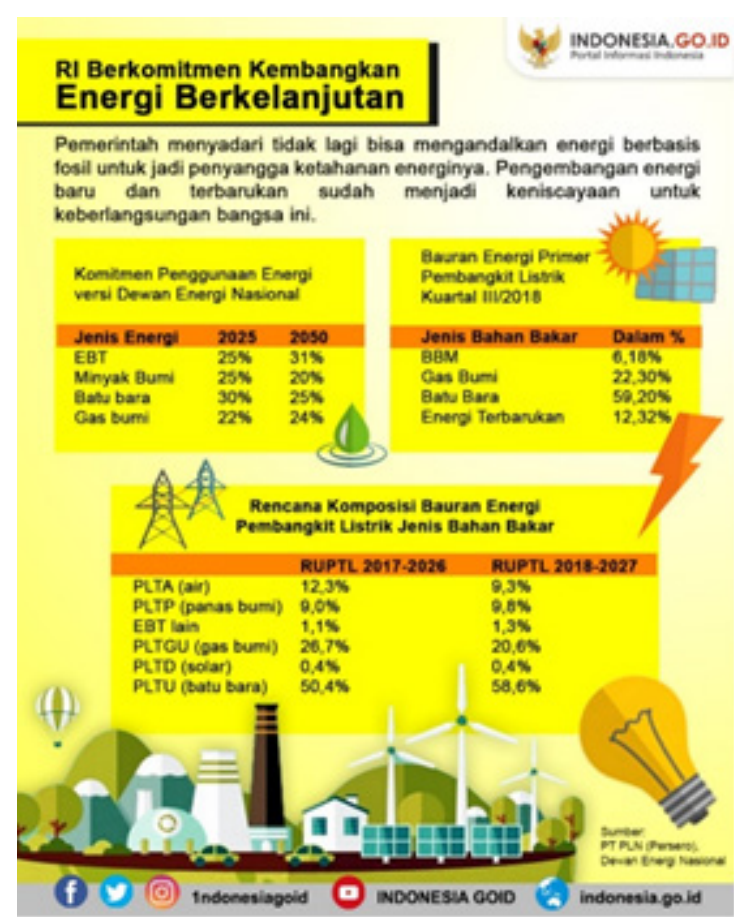

Sumber: Indonesia.go.id, 2018

\section{Gambar 7 Sumber Energi Indonesia}

(Dominick, 2012). Pembuat film Sexy Killers menggambarkan dampak yang muncul akibat penggunaan batu bara sebagai sumber energi pembangkit listrik bertenaga uap.

Sexy Killers menggambarkan kepada khalayak keadaan masyarakat di sekitar lahan tambang batu bara dan juga PLTU. Penggunaan batu bara sebagai sumber energi untuk pembangkit listrik menurut World Coal Association (2020) yang tidak terlepas dari permasalahan kekhawatiran atas penggunaan lahan dan sumber daya air, pencemaran, limbah, dan masalah kesehatan dan keselamatan masyarakat.

Tabel 3 menyatakan bahwa film Sexy Killers merepresentasikan dampak pada unit sosial individu dengan kecondongan pesan yang negatif. Dampak biologis direpresentasikan negatif sebanyak 15 adegan tanpa ada satu pun adegan yang menyatakan memberikan dampak positif terhadap biologis.

Dampak kenyamanan yang direpresentasikan negatif adalah sejumlah delapan adegan, contohnya adegan ketika rumah yang retak maupun hancur akibat penambangan batu bara. Dampak kenyamanan positif sebanyak dua adegan digambarkan dengan aliran listrik yang memadai berkat adanya PLTU sehingga masyarakat bisa beraktivitas tanpa terganggu pemadaman bergilir. Dampak kenyamanan direpresentasikan netral dalam adegan panel surya karena tidak menerangkan kelebihan maupun kekurangan PLTU, namun menginformasikan sumber alternatif pembangkit listrik bagi PLTU.

Dampak psikis yang direpresentasikan sebanyak sebelas adegan merupakan dampak negatif. Sejumlah adegan tersebut menunjukkan individu yang kehilangan sumber pendapatan akibat adanya PLTU maupun pengangkutan

Tabel 3 Tabulasi Silang Dampak Unit Sosial Individu dan Tendensi Pesan

\begin{tabular}{ccccc}
\hline Dampak & \multicolumn{5}{c}{ Tendensi Pesan } \\
Individu & & & & \\
\hline & Positif & Negatif & Netral & Total \\
Biologis & 0 & 15 & 0 & 15 \\
Kenyamanan & 2 & 8 & 1 & 11 \\
Psikis & 0 & 11 & 0 & 11 \\
Total & 2 & 34 & 1 & 37 \\
\hline
\end{tabular}

Sumber: Hasil Penelitian, 2020 
dan penambangan batu bara sehingga adanya penggusuran, kerusakan biota laut, dan penurunan kualitas hasil panen.

Baik sisi pesan maupun tendensi pesan dari film dokumenter Sexy Killers bergantung pada apa yang ingin dicapai oleh sang pembuat film.

Film dokumenter merupakan penggambaran kehidupan nyata yang menggunakan kehidupan nyata sebagai bahan 'mentahnya', namun bukan berarti selalu sesuai dengan kenyataan di lapangan (Aufderheide, 2007).

Film dokumenter ini dikonstruksi oleh sineas yang mempunyai berbagai keputusan untuk menggambarkan apa yang mau diceritakan, kepada siapa cerita tersebut diceritakan, dan apa tujuannya. Adapun yang disampaikan Sexy Killers adalah dampak negatif dari adanya PLTU dan juga penggunaan sumber energi batu bara sehingga kita pun melihat penggambaran di sekitar lahan tambang batu bara yang memberikan efek negatif terhadap lingkungan. Bagi pembuat film Sexy Killers, untuk menggambarkan dampaknya terhadap lingkungan dengan harapan dapat menyadarkan energi batu bara adalah buruk, tentu menggambarkan dengan sisi mana yang ingin ia ceritakan. Hal ini tergambar dalam hasil penelitian bahwa 91,9 persen adegan populasi menggambarkan satu sisi dan sisi lainnya menyampaikan pesan dua sisi.

Sexy Killers melalui pesan yang dampak ekonomi. Dampak ekonomi yang

disampaikan di setiap adegan berusaha menyampaikan dampak buruknya penggunaan PLTU terhadap lingkungan. Film ini juga menyadari listrik yang memadai merupakan kebutuhan masyarakat namun tidak melulu membangun dan mengembangkan PLTU saja. Akan tetapi, pengembangan pembangkit listrik menggunakan sumber energi terbaru. Hal tersebut seperti yang ditunjukkan dalam adegan tentang pemanfaatan energi matahari (surya) sebagai pembangkit listrik menggunakan panel surya.

Dampak pada unit sosial masyarakat paling banyak direpresentasikan yaitu lingkungan hidup. Penggambaran dampak terhadap lingkungan hidup sebanyak 26 adegan bertendensi negatif. Representasi dalam adegan berupa pencemaran baik udara, air, maupun tanah akibat dari debu PLTU dan aktivitas penambangan serta pengangkutan batu bara. Dampak yang direpresentasikan juga berupa berkurangnya ruang terbuka hijau akibat ekspansi PLTU dan juga penggunaan lahan tambang batu bara. Selain itu, dampak lingkungan hidup juga berpengaruh terhadap kualitas hasil perkebunan. Dampak terhadap lingkungan hidup pada unit sosial masyarakat tidak ada satu pun yang direpresentasikan dengan tendensi netral maupun positif.

Pada unit sosial masyarakat juga terdapat 
direpresentasi dengan kecondongan negatif sebanyak delapan adegan ini berbicara mengenai imbasnya pada penurunan penghasilan. Salah satu adegan tentang dampak terhadap ekonomi adalah ketika memperlihatkan Presiden RI sedang meresmikan PLTU Batang. Sexy Killers menampilkan lahan petani yang dibatasi oleh pagar. Lahan pertanian tersebut ditunjukkan telah dicaplok oleh PT PLN sebagai penanggung jawab proyek PLTU Batang ini.

Pesan dampak yang direpresentasikan Sexy Killers tidak semata-mata merupakan proses komunikasi massa saja, tetapi juga tentang bagaimana Sexy Killers melakukan advokasi lingkungan dengan menyadarkan permasalahan lingkungan di sekitar kita melalui komunikasi lingkungan. Advokasi dalam komunikasi lingkungan merupakan tindakan komunikasi dalam rangka mendukung tujuan, kebijakan, ide, atau serangkaian nilai tertentu (Pezzullo \& Cox, 2018). Tindakan yang termasuk dalam fungsi komunikasi lingkungan pragmatic di antaranya adalah mengedukasi, menginformasikan, mewaspadakan, dan meyakinkan atau

Tabel 4 Tabulasi Silang Dampak Unit Sosial Masyarakat dan Tendensi Pesan

\begin{tabular}{lllll}
\hline \multirow{2}{*}{$\begin{array}{l}\text { Mampak } \\
\text { Masyarakat }\end{array}$} & \multicolumn{3}{c}{ Tendensi Pesan } & Total \\
\cline { 2 - 4 } Lingkungan Hidup & 0 & Negatif & Netral & \\
Pendidikan & 0 & 0 & 0 & 26 \\
Ekonomi & 2 & 8 & 0 & 0 \\
\hline Total & 2 & 34 & 1 & 37 \\
\hline
\end{tabular}

Sumber: Hasil Penelitian, 2020 membujuk. Adanya informasi yang telah dibahas sebelumnya yakni penggunaan sumber energi batu bara dibandingkan dengan sumber energi lain juga menjadi contoh fungsi pragmatic ini.

Pembuat film Sexy Killers melalui pesan dampak yang disampaikan berusaha mewaspadakan penggunaan sumber energi batu bara sebagai energi pembangkit listrik. Sebagai upaya mewaspadakan penggunaan sumber energi tersebut, film Sexy Killers memberikan edukasi bahwa asap dari PLTU menghasilkan polutan yang mengandung senyawa berbahaya seperti PM2.5 dan merkuri yang dapat menyebabkan kerusakan otak bahkan jantung. Keberadaan PM2.5 memberikan efek yang berbahaya terhadap manusia yakni seperti efek racun, karsinogen, dan gangguan pernapasan (Bahri, 2018). Hal lain yang juga termasuk dalam fungsi komunikasi lingkungan pragmatic adalah penjelasan asap PLTU yang mengakibatkan adanya kerusakan lingkungan, gangguan kesehatan, gangguan kenyamanan, dan penurunan pendapatan masyarakat.

Fungsi constitutive juga melengkapi tindakan advokasi lingkungan dalam film ini yang membentuk pemahaman dan mengarahkan kesadaran tentang masalah lingkungan, diri manusia, dan alam. Visual yang menampilkan asap dari PLTU, fly ash, laut yang tercemar, pencemaran di sekitar PLTU, dan bentukbentuk kerusakan lain merupakan contoh dari 
fungsi constitutive ini. Fungsi ini membentuk pemaknaan kerusakan lingkungan yang terjadi. Selain itu juga fungsi ini membentuk sikap khalayak bagaimana menghadapi masalah lingkungan yang ada, namun hal ini perlu diteliti lebih lanjut melalui penelitian reception analysis.

Representasi dampak dalam Sexy Killers membawa salah satubentukadvokasilingkungan yakni critical rhetoric. Critical rhetoric adalah bentuk advokasi yang mempertanyakan dan/atau mengkritisi status quo. Critical rhetoric juga merupakan tindakan yang mengartikulasikan sebuah kebijakan alternatif, visi, atau ideologi (Pezzullo \& Cox, 2018). Adegan dalam film ini mengkritisi kebijakan penggunaan sumber energi batu bara dan PLTU melalui penggambaran konsekuensi yang ditimbulkan. Keberadaan komunikasi lingkungan dalam film membawa bentuk advokasi lingkungan sebagai upaya pembelaan untuk menghindari kerusakan lingkungan yang lebih parah. Selain itu juga Sexy Killers berusaha melestarikan lingkungan melalui tindakan critical rhetoric ini.

\section{SIMPULAN}

Sexy Killers merepresentasi dampak biologis pada unit sosial individu dan dampak lingkungan hidup pada unit sosial masyarakat dengan penyampaian pesan pada posisinya sebagai pendukung kelestarian alam, lingkungan, dan kontra terhadap kebijakan pemerintah dalam penggunaan sumber energi batu bara sebagai pembangkit listrik. Pesan dampak disampaikan melalui protes, keluhan, sindiran, maupun sikap mempertanyakan kebijakan pemerintah melalui fungsi komunikasi lingkungan pragmatic dan constitutive sebagai upaya melakukan pembelaan terhadap alam dan lingkungan.

Dampak pada unit sosial individu antara lain biologis lima belas adegan atau 40,6 persen. kenyamanan sebelas adegan atau 29,7 persen, dan psikis sebelas adegan atau 29,7 persen. Dampak pada unit sosial masyarakat di antaranya lingkungan hidup, 26 adegan atau 70,3 persen, ekonomi, sebelas adegan atau 29,7 persen, dan pendidikan tidak muncul. Sexy Killers menggambarkan dampak dengan hanya satu sisi pesan dalam 34 adegan atau 91,9 persen sedangkan dua sisi hanya dalam 3 adegan atau 8,1 persen. Hasil tersebut menunjukkan pesan dampak yang disajikan berisi pesan dukungan pada posisinya sebagai pendukungan lingkungan dan kontra terhadap kebijakan pemerintah menggunakan sumber energi batu bara dan pembangkitnya yakni PLTU. Representasi dampak digambarkan kecondongan negatif dalam 34 adegan atau 91,9 persen sedangkan tendensi positif hanya 2 adegan atau 5,4 persen. Adapun adegan dampak yang netral hanya satu adegan atau 2,7 
persen. Dampak yang disajikan dalam film ini dominan mengandung unsur protes, keluhan, sindiran, dan pendapat negatif berkaitan dengan PLTU. Sexy Killers menggunakan kedua fungsi komunikasi lingkungan pragmatic dan constitutive sebanyak 32 adegan atau 86,5 persen. Adegan yang hanya fungsi pragmatic sebanyak dua adegan atau 5,4 persen dan hanya fungsi constitutive yaitu satu adegan atau 2,7 persen.

Adapun adegan yang tidak termasuk sebagai fungsi komunikasi lingkungan sebanyak dua adegan atau 5,4 persen. Oleh karena itu, keberadaan fungsi tersebut menunjukkan film ini melakukan upaya dalam membela alam dan lingkungan. Adegan critical rhetoric dalam film Sexy Killers sebanyak 35 adegan atau 94,6 persen. Adegan yang tidak termasuk sejumlah dua adegan atau 5,4 persen. Hasil tersebut menunjukkan Sexy Killers sebagai film yang isinya mempertanyakan maupun mengkritisi kebijakan pemerintah. Bentuk usaha pelestarian lingkungan tidak terbatas pada film yang mengandung critical rhetoric, namun adanya film tersebut diharapkan mampu menyadarkan khalayak dalam melestarikan alam di sekitar kita dengan turut berkontribusi mengurangi penggunaan sumber energi batu bara dan kemudian mulai mengganti dengan energi surya yang lebih ramah lingkungan sesuai kemampuan.

\section{DAFTAR PUSTAKA}

Akbar, K. M., Hanief, L., \& Alif, M. (2017). Semangat nasionalisme dalam film (Analisis isi kuantitatif dalam film Merah Putih). ProTVF, 1(2), 125-138. https://doi. org/10.24198/ptvf.v1i2.19872

Ardianto, E., Komala, L., \& Karlinah, S. (2015). Komunikasi massa: Suatu pengantar (R. Karyanti (ed.); Revisi). Simbiosa Rekatama Media.

Aufderheide, P. (2007). Documentary film : a very short introduction. Oxford University Press, Inc.

Bahri, S. (2018). Dampak kesehatan dan lingkungan emisi debu dari aktivitas PLTU Karangkandri Cilacap. Jurnal Rekayasa Teknologi Industri Hijau (RATIH), 3(1), 1-9. https://ejournal.unugha.ac.id/index. $\mathrm{php} / \mathrm{ratih} / \mathrm{article} / \mathrm{view} / 91$

Banjarnahor, D. (2019). Dari 58 Ribu MW, 61\% Pembangkit Listrik RI Masih Batu Bara. CNBCIndonesia. Com. https://www.cnbcindonesia.com/ news/20190923114710-4-101382/dari-58ribu-mw-61-pembangkit-listrik-ri-masihbatu-bara

CNN Indonesia. (2019). Walhi: 10 PLTU Batu Bara Sumbang 30 Persen Polusi Jakarta. https://www.cnnindonesia.com/ nasional/20190716161616-20-412627/ walhi-10-pltu-batu-bara-sumbang-30persen-polusi-jakarta

Dominick, J. R. (2012). Dynamics of Mass Communication: Media in Transition (12th ed.). McGraw-HillEducation.https://books. google.co.id/books?id=09Zk5AAACAAJ

Eriyanto. (2011). Analisis Isi: Pengantar Metodologi untuk Penelitian Ilmu Komunikasi dan Ilmu-Ilmu Sosial Lainnya (Suwito (ed.)). Jakarta: Prenadamedia 
Group.

Firdaus, A. H. (2018). Representasi ideologi khilafah dalam buletin dakwah Kaffah (Studi analisis isi terhadap buletin terbitan Hizbut Tahrir Indonesia) [Skripsi. Universitas Padjadjaran]. https:// repository.unpad.ac.id/frontdoor/index/ index/year/2019/docId/172933

Hansen, A., \& Machin, D. (2013). Researching visual environmental communication. Environmental Communication, 7(2), 151168. https://doi.org/10.1080/17524032.201 3.785441

Ho, S. S., Liao, Y., \& Rosenthal, S. (2015). Applying the theory of planned behavior and media dependency theory: Predictors of public pro-environmental behavioral intentions in Singapore. Environmental Communication, 9(1), 77-99. https://doi.or $\mathrm{g} / 10.1080 / 17524032.2014 .932819$

Indonesia.go.id. (2018). Bauran Energi Indonesia Kian Baik. https://www. indonesia.go.id/narasi/indonesia-dalamangka/ekonomi/bauran-energi-indonesiakian-baik

Kadarisman, A. (2019). Komunikasi Lingkungan: Pendekatan Sustainable Development Goals (SDGs) dan Corporate Social Responsibility (CSR) (N. S. Nurbaya \& F. F. Azhima (eds.)). Simbiosa Rekatama Media.

Karnanta, K. Y. (2012). Ekonomi politik film dokumenter indonesia: dependensi industri film dokumenter indonesia kepada lembaga donor asing. Lakon: Jurnal Kajian Sastra Dan Budaya, 1(1), 1-11. https://doi. org/10.20473/lakon.v1i1.1908

Katadata.co.id. (2016). PLTU Dominasi Pembangkit Listrik di Indonesia. https://databoks.katadata.co.id/ datapublish/2016/09/22/pltu-dominasi- pembangkit-listrik-di-indonesia

Kemdikbud. (2016). KBBI Daring. https://kbbi. kemdikbud.go.id/

Krippendorff, K. (2018). Content analysis: An introduction to its methodology (4th ed.). SAGE Publications. https://books.google. co.id/books?id=FixGDwAAQBAJ

Kurniawan, A. (2015). ANALISIS ISI KRITIK SOSIAL DALAM FILM DOKUMENTER "BELAKANG HOTEL” [Skripsi. UIN Sunan Kalijaga Yogyakarta]. http://digilib. uin-suka.ac.id/18739/

Laksono, D., \& Arz, S. (2019). Sexy Killers. Watchdoc Image. https://www.youtube. $\operatorname{com} /$ watch? $\mathrm{v}=\mathrm{qlB} 7 \mathrm{vg} 4 \mathrm{I}-\mathrm{To}$

McQuail, D. (2012). Teori Komunikasi Massa McQuail (6th ed.). Salemba Humanika.

Keputusan Menteri ESDM Republik Indonesia Nomor 1567 tentang Pengesahan Rencana Usaha Penyediaan Tenaga Listrik PT Perusahaan Listrik Negara (Persero) tahun 2018 s.d. 2027, (2018) (testimony of Menteri Energi dan Sumber Daya Mineral Republik Indonesia). https://web. pln.co.id/statics/uploads/2018/04/RUPTLPLN-2018-2027.pdf

Mudjiono, Y. (2011). Kajian Semiotika Dalam Film. Ilmu Komunikasi, 1(1), 125-138. https://doi.org/10.15642/jik.2011.1.1.125138

Natasha. (2019). Baru tayang 5 hari, sexy killers tembus 14 juta viewers. Liputan6. Com. https://www.liputan6.com/showbiz/ $\mathrm{read} / 3944817 /$ baru-tayang-5-hari-sexykillers-tembus-14-juta-viewers

Permana, R. S. M., Puspitasari, L., \& Indriani, S. S. (2019). Industri film Indonesia dalam perspektif sineas Komunitas Film Sumatera Utara. ProTVF, 3(2), 185-199. https://doi. org/10.24198/ptvf.v3i2.23667

Pezzullo, P. C., \& Cox, R. (2018). Environmental 
communication and the public sphere (5th ed.). SAGE Publications.

Prakoso, B. A., Rostyaningsih, D., Sundarso, \& Marom, A. (2016). Evaluasi Dampak Pembangunan Pembangkit Listrik Tenaga Uap (PLTU) Tanjung Jati B di Desa Tubanan Kecamatan Kembang Kabupaten Jepara. Journal of Public Policy And Management Review, 5(2), 208-222. https://doi.org/10.14710/jppmr.v5i2.10898 Pramanik, R. A., Purnomo, E. P., \& Kasiwi, A. N. (2020). Dampak perizinan pembangunan pltu batang bagi kemajuan perekonomian masyarakat serta pada kerusakan lingkungan. Kinerja, 17(2), 248-256. https://www.researchgate. net/publication/346677250_Dampak_ perizinan_pembangunan_PLTU_ batang_bagi_kemajuan_perekonomian_ masyarakat_serta_pada_kerusakan_ lingkungan

Ratnasari, A. (2010). Pesan Positif dalam Komunikasi. MIMBAR, XXVI(2), 159-168. https://ejournal.unisba.ac.id/index.php/ mimbar/article/view/302/76

Safanayong, Y. (2006). Desain komunikasi visual terpadu. Jakarta: Arte Intermedia.

Sari, N. L. D. I. D. (2013). Elemen Visual Kemasan Sebagai Strategi Komunikasi Produk. Profetik, 6(1), 43-52. http:// ejournal.uin-suka.ac.id/isoshum/profetik/ article/view/1175

Tumbol, M. P. (2015). Dampak Pembangunan Pembangkit Listrik Tenaga Uap (PLTU) Banten 2 Labuan pada Kehidupan Sosial
Ekonomi Masyarakat di Desa Cigondang Kecamatan Labuan-Banten [Skripsi, Universitas Sultan Ageng Tirtayasa]. http://repository.fisip-untirta.ac.id/588/1/ Melinda Paula Tumbol_6661110006 Copy.pdf

Urbani, Y. H., \& Purnama, B. E. (2011). Produksi Film Indie Komersial “ Aku Cinta Indonesia - Generation " Berbasis Multimedia. Journal Speed, 9(3), 1-10. https://doi.org/10.3112/speed.v3i3.927

Venus, A. (2018). Manajemen Kampanye: Panduan Teoritis dan Praktis dalam Mengefektifkan Kampanye Komunikasi Publik (R. K. Soenendar (ed.); Revisi). Simbiosa Rekatama Media.

Watchdoc Image. (2019). SEXY KILLERS (Full Movie). https://www.youtube.com/ watch? $=\mathrm{q} 1 \mathrm{~B} 7 \mathrm{vg} 4 \mathrm{I}-\mathrm{To}$

World Coal Association. (2020). Coal use \& the environment. https://www.worldcoal. org/environmental-protection/coal-useenvironment

Yenrizal, Y. (2017). Lestarikan Bumi dengan Komunikasi Lingkungan (T. Wijaya \& H. Yusalia (eds.)). Deepublish. http:// eprints.radenfatah.ac.id/3937/1/E BOOK Lestarikan Bumi dengan Komunikasi Lingkungan_v.4.0_Unesco_ebook.pdf Zikargae, M. H. (2018). Analysis of environmental communication and its implication for sustainable development in Ethiopia. Science of the Total Environment, 634, 1593-1600. https://doi.org/10.1016/j. scitotenv.2018.04.050 